\title{
Some observations from the excavation of honey mesquite
}

root systems

\section{R. K. HEITSCHMIDT, R.J. ANSLEY, S.L. DOWHOWER, P.W. JACOBY, AND D.L. PRICE}

\begin{abstract}
A single, mature and 12 smaller honey mesquite (Prosopis glandulosa Torr. var. glandulosa) trees were partially excavated during 1986 to examine root distributional patterns. The mature tree had an extensive lateral root system and a large tap root that subdivided into 3 smaller tap roots at a depth near $1 \mathrm{~m}$. The lateral root system of all trees was concentrated in the upper $0.3 \mathrm{~m}$ of the soil profile. Results from the excavations provide evidence in support of honey mesquite's classification as a facultative phreatophyte.
\end{abstract}

Key Words: Prosopis glandulosa, leaf area, biomass, dry weight

Dense stands of honey (Prosopis glandulosa Torr. var. ) and velvet [P. glandulosa var. velutina (Woot.) Sarg.] mesquite impact extensive areas of rangeland in the southwestern United States (Fisher 1977). Mesquite's persistence following establishment is believed to be related to its facultative phreatophytic strategy (Thomas and Sosebee 1978) which is related to its ability to extract water from a large volume of soil (Fisher et al. 1959, Phillips 1963, Fisher et al. 1973, Ludwig 1977) in a preferential sequence from near the soil surface downward (Haas and Dodd 1972, Easter and Sosebee 1975), while maintaining acute physiological control of transpirational water losses (Mooney et al. 1977, Nilsen et al. 1981).

The objective of this note is to describe the root distributional patterns of partially excavated honey mesquite trees in the Rolling Plains of Texas. Results from 2 studies are described. The first study was undertaken to provide critical information needed to satisfactorily develop dynamic water yield/water use simulations models for honey mesquite infested rangelands. The second study was undertaken to quantify the effect of soil type on the lateral and vertical distribution of roots.

\section{Materials and Methods}

Both study sites were located on the eastern edge of the Rolling Plains in north central Texas. Climate is semiarid continental characterized by warm, wet springs and falls, hot summers, and mild winters. Average annual precipitation is about $65 \mathrm{~cm}$. Herbaceous vegetation is a mixture of short and midgrasses. Dominant herbaceous species in this region are buffalograss [Buchloe dactyloides (Nutt.) Engelm.], sideoats grama [Bouteloua curtpendula Michx.) Torr.], Texas wintergrass (Stipa leucotricha Trin. and Rupr.), and Japanese brome (Bromus japonicus Thunb.). Honey mesquite is the dominant woody plant.

\section{Study 1}

The study site was located on the Wagon Creek Spade ranch in Throckmorton County. A single-stemmed, mature honey mesquite tree growing within a dense $(>500$ trees/ha) stand of trees was partially excavated during the summer of 1986 (Fig. 1). The tree was located on a nearly level upland site. Soils within the

Authors are professor, post-doctorate, research associate, and professor, respectively, Texas Agricultural Experiment Station, Box 1658, Vernon 76384; and postdoctorate, Range Science Department, Texas A\&M University, College Station 77843.

Research was supported in part by grants from the E. Paul and Helen Buck Waggoner Foundation and the USDA Soil Conservation Service, RCA Special Study No. 58-7442-4-2800. Appreciation is extended to the Wagon Creek Spade and W.T. Waggoner Ranches for providing research areas.

Manuscript approved for publication by the Director, Texas Agr. Exp. Sta. as TA 23093.

Manuscript accepted 1 February 1988.

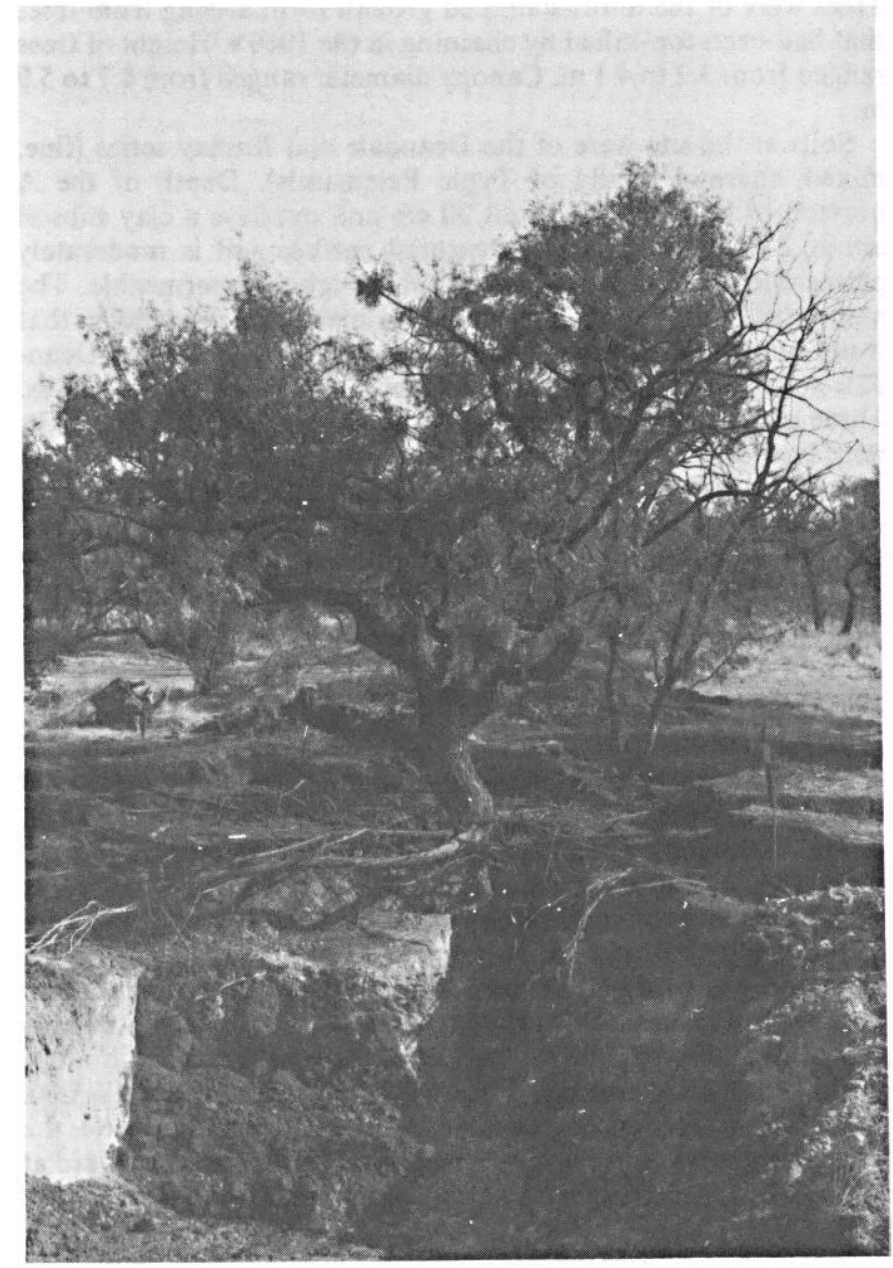

Fig. 1. Mature honey mesquite tree following partial excavation of root system.

excavation pit graded from a Nuvalde clay loam (fine-silty, mixed, thermic family of Typic Calciustolls) on the south to a Valera clay loam (fine, montmorillonitic, thermic family of Petrocacic Calciustolls) on the north. Solum depth ranged from about $50 \mathrm{~cm}$ on the north to $90 \mathrm{~cm}$ on the south. Both soils are moderately permeable and are formed over rather impermeable, cemented calcium carbonated alluvium.

Hand excavation of the $6 \mathrm{~m}$ tall tree began in early summer and was completed by mid-August. During excavation, no accelerated leaf abscission was observed. Thus following excavation, all leaves were removed by hand, dried at $60^{\circ} \mathrm{C}$ to a constant weight and weighed to estimate total leaf biomass. Total leaf area ( 1 side) was estimated using a linear regression derived from subsample relationships between leaf dry weights and leaf area as estimated using a leaf area meter. Following the abscission of a second set of leaves in late September, the aboveground portion of the tree was harvested by hand and weighed. Dry weight was estimated by drying 
subsamples of various size classes of limbs to a constant weight and weighing.

\section{Study 2}

The second study site was located approximately $40 \mathrm{~km}$ north of the first on the W.T. Waggoner ranch in Wilbarger County. Study was conducted during the excavation and subsequent containerization of 12 honey mesquite trees being prepared for ecophysiology stress studies (Ansley et al. 1988). The site was located on a nearly level upland. Density of trees was about 400 plants/ha. Trees were of the multi-stemmed growth form arising from trees that had been top-killed by chaining in the 1960's. Height of trees ranged from 3.2 to $4.1 \mathrm{~m}$. Canopy diameter ranged from 4.7 to 5.9 $\mathrm{m}$.

Soils at the site were of the Deandale and Kamay series (fine, mixed, thermic family of Typic Paleustolls). Depth of the A horizon of both soils is about $30 \mathrm{~cm}$ and overlays a clay subsoil about $2 \mathrm{~m}$ thick. The clay textured surface soil is moderately permeable whereas the clay subsoil is highly impermeable. The major difference between the soils is related to micro-relief in that water tends to accumulate on the level to slightly concave Deandale soils and run off the nearly level (1-3\% slope) Kamay soils. Three study trees were located on the Deandale soils and 9 trees were located on the Kamay soils.

Following mechanical removal of the soil around the periphery of the trees, numbers of roots $(>2 \mathrm{~mm}$ in diameter) were counted along the 6 exposed faces of the trend. A 2- $\mathrm{m}^{2}$ frame of $0.3-\mathrm{m}^{2}$ grids were utilized to quantify the vertical distribution of roots along each 4-m-wide by 2-m-deep face (Fig. 2).

\section{Results}

\section{Study 1}

Complete excavation of the tree was not possible because of labor constraints (Fig. 1). However, partial excavation revealed several interesting phenomena. Major lateral roots were located generally in the upper $30 \mathrm{~cm}$ of the soil profile (Fig. 3). These roots in turn gave rise to 2 major types of secondary roots. The first were of the small ( $<5 \mathrm{~mm}$ in diameter) fibrous type that extended upward toward the soil surface. These roots were most abundant on the north and east side of the tree and were restricted primarily to the soil under the canopy. The second type were larger (about 20 mm in diameter) and extended downward through the calcified Chorizon. A single lateral root was excavated from its origin at the base of the tree to a point about $10 \mathrm{~m}$ away from which it turned downward at a right angle. At its origin it was approximately $60 \mathrm{~mm}$ in diameter. At the point where it turned downward it was about $8 \mathrm{~mm}$ in diameter and about $50 \mathrm{~cm}$ below the soil surface. One larger lateral root (about $30 \mathrm{~mm}$ in diameter) was found to sequentially turn downward for about $20 \mathrm{~cm}$, upward for about $30 \mathrm{~cm}$, then downward again all within a horizontal distance of about $20 \mathrm{~cm}$.

The vertical root system excavated under the trunk initially consisted of a single tap root (Fig. 4). At a depth near $90 \mathrm{~cm}$, approximately $10 \mathrm{~cm}$ below the beginning of the $C$ horizon, the tap root became horizontal before subdividing into 3 roots, 2 extending downward and 1 extending horizontally and then upward. Vertical excavation was halted at a depth near $130 \mathrm{~cm}$.

Harvest of the aboveground portion of the tree yielded a total of $7,377 \mathrm{~g}$ (dry weight) of leaves. The linear regression of the leaf area and dry-weight estimates derived from leaf subsamples was LA = $-17.1+65.0 \mathrm{X}$ where LA equaled leaf area $\left(\mathrm{cm}^{2}\right)$ and $\mathrm{X}$ equaled weight $(\mathrm{g})\left(R^{2}=0.996, n=51\right)$. Total estimated leaf area ( 1 side) was $47.95 \mathrm{~m}^{2}$. Measured ground area of canopy was approximately $43.4 \mathrm{~m}^{2}$ yielding a leaf area index of 1.104 . Estimated wet weight of aboveground woody tissue was $320 \mathrm{~kg}$. Mean water content ranged from about $40 \%$ (twigs) to $28 \%$ (trunk) and estimated total woody dry weight was $219 \mathrm{~kg}$.

\section{Study 2}

Averaged across soil series, counted root intercepts on faces of

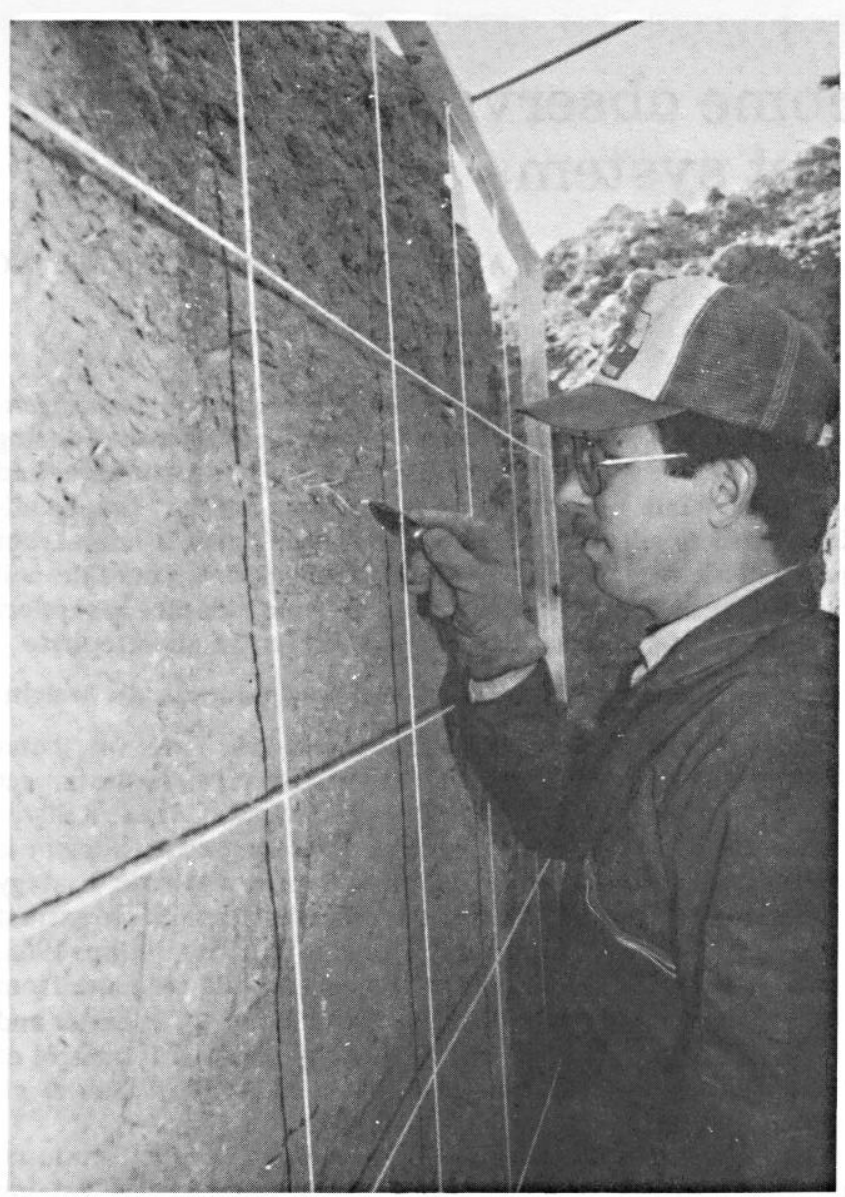

Fig. 2. Counting number of roots along face of 1 of 6 trenched walls around small honey mesquite tree (see Ansley et al. 1988).

the barrier cuts showed $81 \%$ of all roots occurred within the top $1 \mathrm{~m}$ of the soil profile. The number of roots diminished progressively from $42 \%$ of the total in the top $30 \mathrm{~cm}$ of the soil profile to $4 \%$ at the 2-m depth.

The effect of soil series on root distributional patterns was expressed in 2 manners (Fig. 5). Firstly, root densities in the top 30 $\mathrm{cm}$ of the soil profile were greater in the Deandale $\left(43 / \mathrm{m}^{2}\right)$ than the Kamay $\left(33 / \mathrm{m}^{2}\right)$ soil. Densities at the lower depths were similar. Secondly, there was a greater number of roots on the eastnortheast side of the trees growing on the Kamay soils than on the south-southwest side which agreed with the general observations from Study 1. However, no directional pattern was evidenced by the trees growing on the Deandale soil.

Definitive explanations for these differences between soils in root distributional patterns were not readily apparent. It is hypothesized however, that they may be related to differences in soil water dynamics in that water often stands on the Deandale soils as opposed to running off the Kamay soils. 

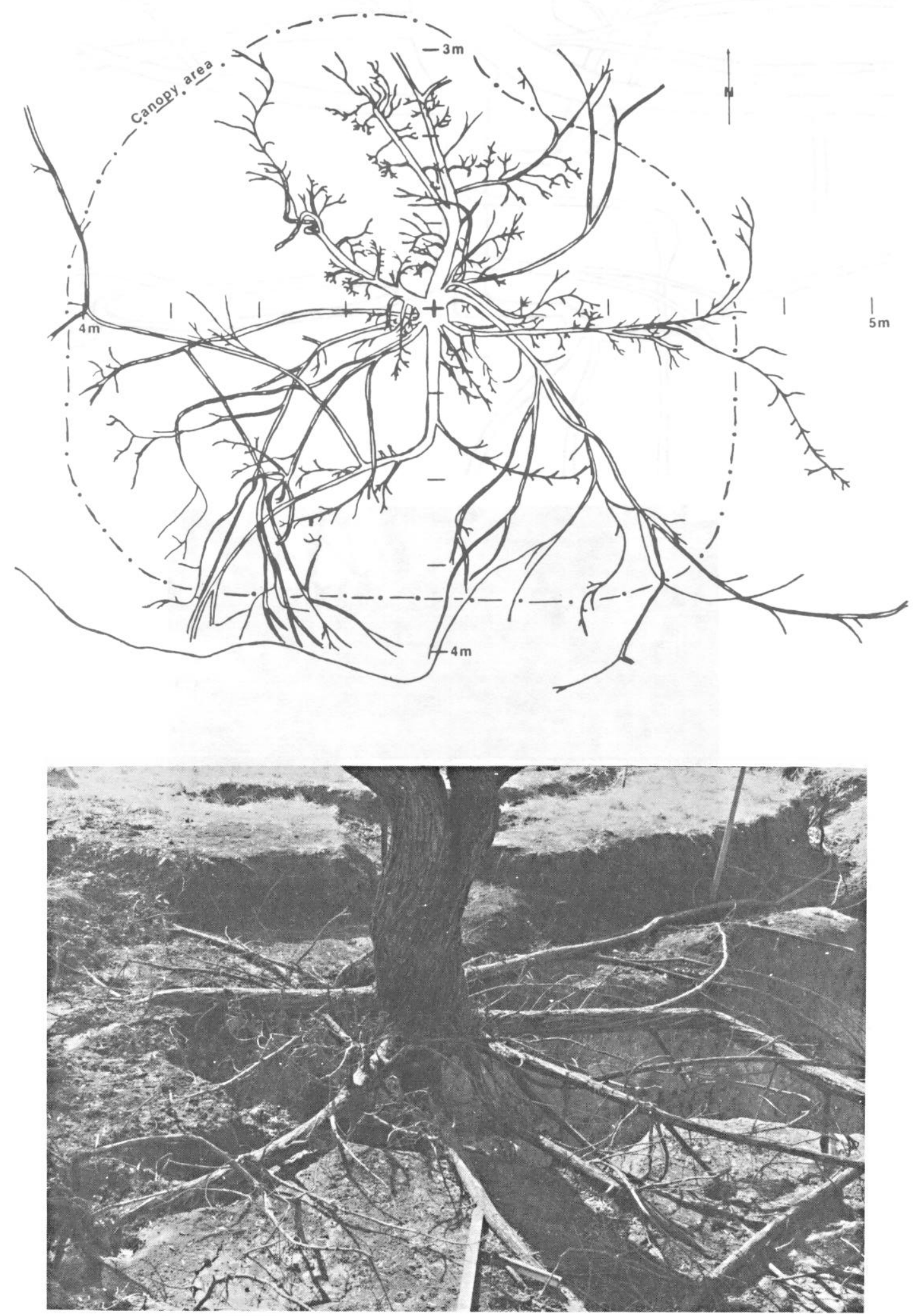

Fig. 3. Picture and scaled drawing of lateral root system in upper $0.25 \mathrm{~m}$ of soil profile of mature honey mesquite tree. 

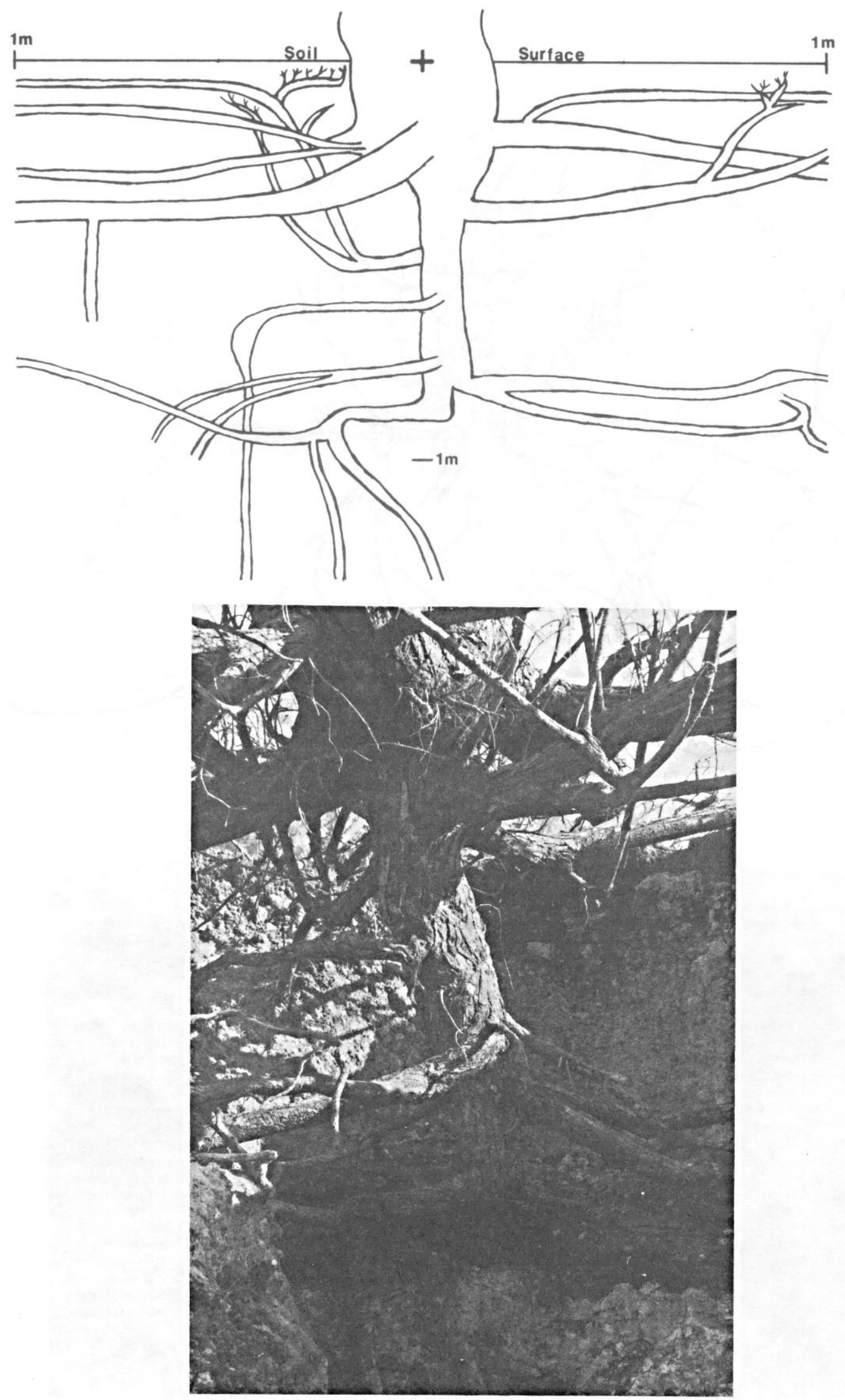

Fig. 4. Picture and scaled drawing of tap root of mature honey mesquite tree. 


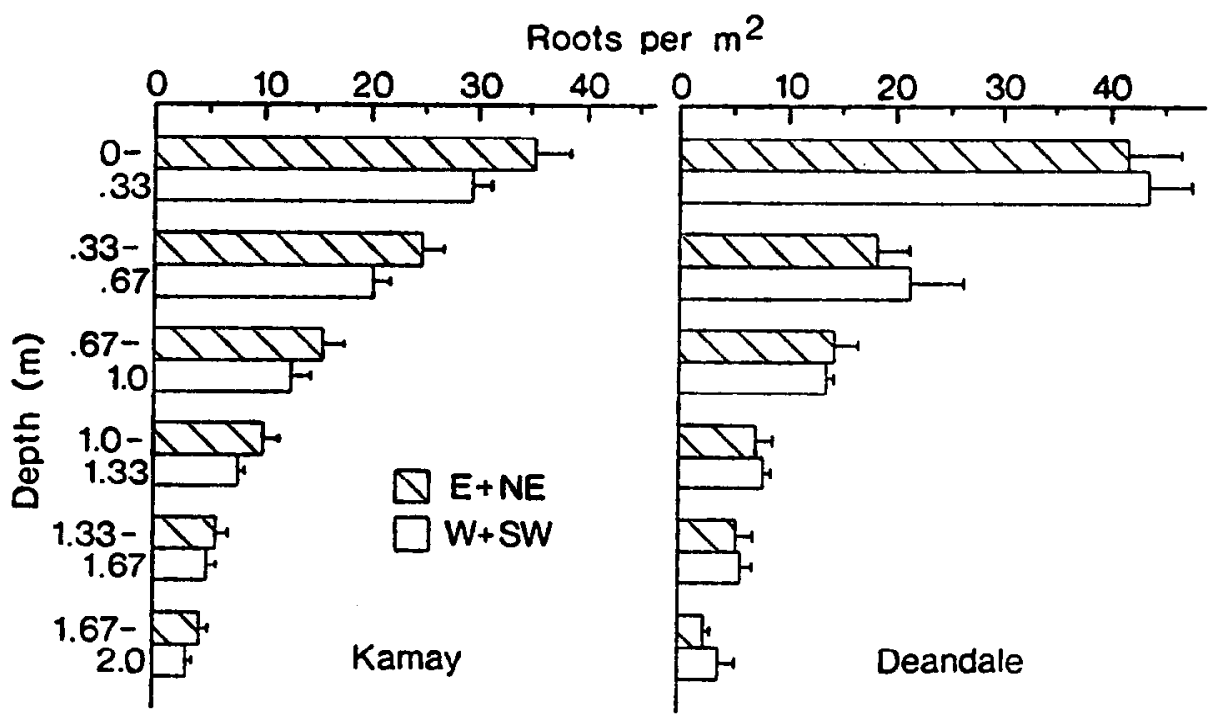

Fig. 5. Number of roots $\left(m^{2}\right)$ at various depths along north-northeast and west-southwest trenched walls of small honey mesquite trees growing in Kamay and Deandale soil series. Vertical lines represent $\pm S . E$. of $\bar{x}$.

\section{Literature Cited}

Ansley, R.J., P.W. Jacoby, and B.K. Lawrence. 1988. Root containerization for physiological studies of shrubs and trees on rangeland. J. Range Manage. 41:90-91.

Easter, S.J., and R.E. Sosebee. 1975. Influence of soil-water potential on the water relationships of honey mesquite. J. Range Manage. 28:230-232.

Fisher, C.E. 1977. Mesquite and modern man in Southwestern North America. p. 177-188. In: B.B. Simpson (ed.), Mesquite, its biology in two desert ecosystems. US/IBP Synthesis Ser. 4. Dowden, Hutchinson and Ross. Stroudsburg, Penn.

Fisher, C.E., G.O. Hofiman, and C.J.Scifres. 1973. The mesquite problem. In: Mesquite growth and development, management, economics, control, uses, Texas Agr. Exp. Sta. Res. Mono. 1.

Fisher, C.E., C.H. Meadors, R. Behrens, E.D. Robinson, P.T. Marion, and H.L. Morton. 1959. Control of mesquite on grazing lands. Tex. Agr. Exp. Sta. Bull. 935.

Hans, R.H., and J.D.Dodd. 1972. Water stress patterns in honey mesquite. Ecology 53:674-680.
Ludwit, J.A. 1977. Distributional adaptations of root systems in desert environments. p. 85-91. In: J.K. Marshall (ed), The belowground ecosystem: a synthesis of plant-associated processes. Range Sci. Dept., Colorado State Univ., Fort Collins, Colo.

Mooney, H.A., B.B. Simpson, and O.T. Solbrig. 1977. Phenology, morphology, physiology. p. 26-43. In: B.B. Simpson (ed.) Mesquite-Its biology in two desert ecosystems. US/IBP Synthesis Ser. 4. Dowden, Hutchinson and Ross. Stroudsburg, Penn.

Nilsen, E.T., P.W. Rundel, and M.R. Sharif. 1981. Summer water relations of the desert phreatophyte Prosopis glandulosa in the Sonoran Desert of Southern California. Oecologia (Berlin) 50:271-276.

Phillips, W.S. 1963. Depth of roots in soil. Ecology 44:424.

Thomas, G.W., and R.E. Sosebee. 1978. Water relations of honey mesquite-a facultative phreatophyte. p. 414-418. In: Proc. 1st Internat. Rangeland Cong. (ed. D.N. Hyder), Soc. Range Manage. Denver, Colo. 